\title{
Geographical Indication and Regional Development: Cause or Consequence
}

\author{
Alan Malacarne ${ }^{1}$, Liaria Nunes da Silva ${ }^{1}$, Camila Souza Vieira ${ }^{1}$, Ricardo Fontes Macedo ${ }^{1}$, Andreia Malacarne ${ }^{2}$, \\ Washington Sales do Monte ${ }^{1} \&$ Robelius De-Bortoli ${ }^{1}$ \\ ${ }^{1}$ Federal University of Sergipe, São Cristóvão, Brazil \\ ${ }^{2}$ Federal University of São João del Rei, São João del Rei, Brazil \\ Correspondence: Alan Malacarne, Federal University of Sergipe, Residencial Universidade Center, Number: 784, \\ Apartment: 204, Street Major Teles de Menezes, Jd. Rosa Elze, CEP: 49100-000, São Cristóvão, Sergipe, Brazil. \\ Tel: 55-027-99801-1662. E-mail: alanmalacarne1988@gmail.com
}

Received: November 22, 2018

Accepted: December 27, 2018

Online Published: February 15, 2019

doi:10.5539/jas.v11n3p535

URL: https://doi.org/10.5539/jas.v11n3p535

The research is financed by FAPITEC-Foundation for Research and Technological Innovation Support of the State of Sergipe.

\begin{abstract}
The Geographical Indication is an instrument of protection to products and services that have intrinsic value. The cities of Bento Gonçalves, Flores da Cunha, Monte Belo do Sul, Farroupilha, Paraty, Urussanga, Salinas and Abaíra are highlights in the Brazilian agricultural sector. These regions have territorial demarcations with a Geographical Indication certification, where the producers live in the same region and can sell their own products with this seal of quality. An analysis has as a starting point the following study problem: Is the success of the implementation of a Geographical Indication linked to the development of the region? The results showed that only the Gross Domestic Product per capita is not sufficient to prove a record of Geographic Indication was actually implemented successfully in a certain region or not, however it can be observed that in the developed regions the trend is much higher.
\end{abstract}

Keywords: geographical indication, regional development, gross national product, agribusiness

\section{Introduction}

The Gross National Product (GNP) is a set of statistical data with variables that establish macroeconomic relations, making it possible to trace its sectoral and economic profile to the locality in question (IBGE, 2015a). The city of Presidente Kennedy, located in the interior of the state of Espírito Santo, despite its simplicity has the highest GNP per capita in the country, with an impressive mark of R\$ 513,1 thousand real (IBGE, 2015b). This data, when compared to the GNP of the largest and most developed capital of the country, São Paulo, which has GNP per capita of R\$ 54,4 thousand real will be observed that the former has a GNP almost ten times greater (IBGE, 2015c). The city of President Kennedy has this high GNP per capita due to the oil industry that developed on the south coast of Espírito Santo, but according to Hunter and Monte (2015) the royalties that the city receives did not contribute to the improvement of development indicators.

A form of regional development is conceptualized as endogenous development, which implies the ability to aggregate value over production and the capacity of the region to absorb the benefits of this production, increasing local income and the supply of jobs (Amaral Filho, 2001). In this example we have the cities of Bento Gonçalves and Monte Belo do Sul which are part of the Serra Gaúcha, the most important wine region in the country. Due to the organization of the producers of the region, the Association of Producers of Fine Wines the Vinhedos Valley was formed, APROVALE (Tonini, 2008). This was the first Brazilian region to obtain Geographical Indication (GI) certification for wines with the origin name Vale dos Vinhedos. Monte Belo do Sul besides owning the GI of geographical name Vale dos Vinhedos, also has another certification of this type that takes the name of Monte Belo. The cities of Farroupilha and Flores da Cunha also located in the Serra Gaúcha have GI of the wine with geographic names of Farroupilha and Altos Montes (INPI, 2018). On the other hand, the city of Parati in Rio de Janeiro has registration GI for cachaça, this city is traditional in this type of 
agribusiness, where most of the sugar cane production goes to manufacturing cachaça (Oliveira \& Andrade, 2009).

What these cities have in common besides the GI registry is the tradition in agribusiness and the ability to organize in associations and cooperatives in order to achieve a common good that is regional socioeconomic development. These regions of Rio Grande do Sul, with a wine production culture, were colonized by Italian immigrants looking for lands with similar climate and relief of Italy, producing a quality product, combining the edaphoclimatic factors with the appropriate handling for the production, which made the winemaking of Rio Grande do Sul prosper (Paz \& Baldisserotto, 1997; Tonietto, Falcade, \& Taffarel, 2005). In Parati since the 18th century, cachaça was already exported to countries of the African continent and to Portugal, and the history of this cachaça is merged with that of Brazil colony and the work of slaves (Oliveira \& Fraga, 2011).

From this point of view we can see that these regions and their products contain a tradition and a history that is secular. Some time now its products have been improved by the regional producers, and the know-how (appropriate handling) combined with the particularities of the regions makes these products have an added value. This added value does not come from the GI registry, it is intrinsic, the GI only assures this value by protecting the product against possible imitations and evidencing the qualities of the product for the consumer. The studies by Silva et al. (2018) show that the great majority of GI certifications are in the South and Southeast regions, according to the author several factors influence on an application for registration of GI, among them highlights the existence of structured local productive arrangements, a associative capacity of producers, socio-economic development of the region, as well as support from public organizations in the procedures for the preparation of request. Thus the present work brings the following question: Is the success of implementing a GI linked to the development of the region? In view of this issue, it will be worked on and discussed statistically comparing the GNP per capita the main citys of GI of the agribusiness, specifically of the ethyl beverages, with the GNP per capita of their states.

\section{Material and Method}

Will be presented the material and the method utilized in the present research, the identifying the type of research, how was the gathering data the data and which the procedures used.

\subsection{Research Design}

This is a basic research as it geared toward the generation of new knowledge. In relation to the objectives, it is characterized as descriptive, as it establishes patterns of data collection techniques. Regarding the problem approach, the research translates the information into numbers, and in the sequence presents an interpretative approach to the reality of the data (Vergara, 1990; Kauark, Manhães, \& Medeiros, 2010; Marconi \& Lakatos, 2017).

\subsection{Data Collect}

A bibliographic survey was carried out on the bases of public domain and documentary search on the websites of the National Institute of Industrial Property (INPI) and the Brazilian Institute of Geography and Statistics (IBGE). In the INPI, the data of the registries granted of GIs were accessed, collecting the geographical name and the date of concession of the GIs of the Agribusiness, finally were selected only those that represented the ethylic beverages. In the IBGE database were collected the GNP per capita data of the main cities of the GIs of ethyls beverages in the period from 1999 to 2015 and from their respective states. Specific information was also collected on articles and books on the topic researched.

\subsection{Procedures}

After collecting and grouping the data of the Agribusiness GIs in an Excel spreadsheet, highlighting the GIs of ethylic beverages, was identified the main cities of the GIs and the states to which they belong. Were added data of the per capita GNP of the cities and states. Next, a bibliographical search was made on suitable articles and books on GIs and territorial development, in order to give a theoretical basis to the research.

\subsection{Statistical Analysis}

The t-student test was used to assess differences between paired means from Average per capita GNP of main cities of the GIs in relation to their state. A significance level of $\mathrm{p}<0.01$ was used throughout the study.

\section{Results}

It is observed in Figure 1 that in the state of Rio Grande do Sul, there are examples of cities in which regional development is notorious, such as the cities of Bento Gonçalves, Flores da Cunha, Monte Belo do Sul and Farroupilha. It is also noticed that they have a GNP per capita higher than the average of their state, as well as 
the city of Parati in Rio de Janeiro, which also has an average GNP per capita higher than that of the state (IBGE, 2015). These cities have a history of local production and development that send to their colonizers, whether Italian or Portuguese immigrants.

The socioeconomic growth of these regions happened gradually, probably due to this historical construction, confirming Coronel, Alves, and Amaral (2007) when they affirm that the work of the immigrants was very beneficial to the social and economic development of Rio Grande do Sul. It can be said that the high rate of development of cities such as Bento Gonçalves, Flores da Cunha, Monte Belo do Sul, Farroupilha and Paraty was essential for them to obtain the GI registry and to actually implement this registry.

The cities of Urussanga in the state of Santa Catarina, Salinas in Minas Gerais and Abaíra in Bahia can also be observed in Figure 1, where their GNP per capita is not higher than its respective state. While Urussanga has a small difference from the average per capita GNP of Santa Catarina, Salinas and Abaíra have an average of less than half in relation to their states.

Table 1. Average per capita GNP of main cities of the GIs in relation to their state

\begin{tabular}{|c|c|c|c|}
\hline & Average GNP/per capita & $\mathbf{t}$ & $\mathrm{p}<0.01$ \\
\hline Rio Grande do Sul & $\mathrm{R} \$ 18.196,09$ & & \\
\hline Bento Gonçalves & $\mathrm{R} \$ 25.992,58^{*}$ & 2.17 & 0,00 \\
\hline Flores da Cunha & $\mathrm{R} \$ 23.285,74^{*}$ & 1.5 & 0.00 \\
\hline Monte Belo do Sul & $\mathrm{R} \$ 21.814,35^{*}$ & 0.98 & 0.00 \\
\hline Farroupilha & $\mathrm{R} \$ 23.290,13^{*}$ & 1.63 & 0.00 \\
\hline Santa Catarina & $\mathrm{R} \$ 19.506,21$ & & \\
\hline Urussanga & $\mathrm{R} \$ 18.737,74$ & 0.23 & 0.00 \\
\hline Rio de Janeiro & $\mathrm{R} \$ 22.170,06$ & & \\
\hline Parati & $\mathrm{R} \$ 26.392,41^{*}$ & 0.55 & 0.00 \\
\hline Minas Gerais & $\mathrm{R} \$ 13.853,57$ & & \\
\hline Salinas & $\mathrm{R} \$ 6.112,16$ & 4.11 & 0.00 \\
\hline Bahia & $\mathrm{R} \$ 8.471,63$ & & \\
\hline Abaíra & $\mathrm{R} \$ 3.162,10$ & 5.04 & 0.00 \\
\hline
\end{tabular}

Note. *There were significant differences with values higher than the mean of their state (t-Student test).

It can be noted in Table 2 that there is an inverse relationship between rural population and development success (if by taking into account GNP per capita), because the lowest percentage of the population is related to a better ratio per capita GNP/municipality/state. The city of Monte Belo do Sul is an exception, but this may be due to the fact that the city has a few inhabitants. The reason for the municipalities with the highest rural population index tue a per capita GNP lower than that of their states, may be linked to subsistence farming, which contributes little to regional development, since it is a modality of agriculture that only serves for the survival of the farmer. According to Wharton (2017) studies, subsistence agriculture is a worldwide problem and there are few policies and programs for the development of this sector. Contrary to popular belief, IG can not solve this problem because it is only a protection for a product that already has added value, as well as all other subdivisions of Intellectual Property.

Table 2. Rural and urban population of the main cities of the GIs

\begin{tabular}{lll}
\hline & Rural & Urban \\
\cline { 2 - 2 } & $4.580(55 \%)$ & $3.736(45 \%)$ \\
Bento Gonçalves & $8.209(8 \%)$ & $99.069(92 \%)$ \\
Farroupilha & $8.582(13 \%)$ & $55.053(87 \%)$ \\
Flores da Cunha & $6.271(23 \%)$ & $20.855(77 \%)$ \\
Monte Belo do Sul & $1.900(71 \%)$ & $770(29 \%)$ \\
Parati & $9.844(26 \%)$ & $27.689(74 \%)$ \\
Salinas & $8.462(22 \%)$ & $30.716(78 \%)$ \\
Urussanga & $8.818(44 \%)$ & $11.405(56 \%)$ \\
\hline
\end{tabular}

Source: IBGE Census 2010. 


\section{Discussion}

The studies by Silva et al. (2018) show that the most developed regions of the country (Southeast and South) are those with the highest number of GI records, having the Southeast 32\% of records of Indication of Provenance (IP) and $50 \%$ of the registers of Denominations of Origin (DO), while the South region holds $33 \%$ of PI records and $30 \%$ of DO records, which are the two categories in which GIs are divided. In this way it is possible to report that there is a relationship between regional development and the success of the GI registry. It is noticed that it is not worth having a record where one does not have a management with effective strategies to implement this certification. According to Fonseca Veiga (2001) Strategic Management is essential for organizations that seek success in a highly competitive market.

According to Porter (2009), the implementation of an organizational strategy assists the organizations that produce a differentiated product in the loyalty of clients that seek a certain quality standard. Since IG is a certification for products differentiated by its quality standard, it is understood that the registration of these products in the National Institute of Industrial Property (INPI) alone does not bring benefits to producers, there needs to be a organizational process with strategies aimed at the management of this certification for the insertion of the products belonging to it in the market.

By transforming into just a number the whole result of economic activity of a region in a certain period, GNP is one of the best ways to measure the regional development of a given region (Mankiw, 2014). However, according to Cassano et al. (2017), GNP is not an indicator of development, but an indicator of economy, because the development of a region is not only linked to GNP, this includes broader factors such as population well-being and levels of inequality. Thus, it can be understood that only GNP data may not be enough to analyze regional development as a whole, but it is an official fact that the government uses to monitor the economy of the country, and can measure the production of a certain region.

It is important to analyze the GNP per capita of the GI holding regions, since the GIs protect the value added in products or services (Brasil, 1996). However, the effectiveness of a GI registry is not only linked to GNP, but rather in a regional development in its totality, that is, the more developed the region the greater the probability of success with this GI record.

The records of agribusiness GIs are more frequent in regions where family farming predominates, this is an important fact regarding the social and economic development of small and medium-sized rural properties. The GIs are normally required by cooperatives and associations, thus having several producers involved, contributing to the generation of the region's GNP. Another associative work is in the region of Salinas, in Minas Gerais, which holds the IP registration of cachaça. In this region there is a great use of rural labor, most of which is carried out by small farmers and their families. The Association of Cachaça Producers of Alambique de Salinas (APACS) has about 60 brands of cachaça (Oliveira \& Costa, 2014). In this way it can be understood that the protection of GIs is to guarantee the added value of the product, protecting the producing region and the people that remain there.

According to Mattei (2014), family farmers' establishments occupy 12.3 million people while large estates occupy only 4.3 million people. This means that family farming accounts for $75 \%$ of rural occupations. The author also points out that in territories where family farming predominates there is greater preservation of the environment and better territorial distribution of the inhabitants, which does not occur in the agribusiness of large latifundia, since there is little concern with the environment and the number of workers is limited. For example, it is possible to cite the GI records of the extractivism, such as IP for the marble of Cachoeiro de Itapemirim, in the state of Espírito Santo or the Region of Pedra Carijó in Rio de Janeiro with extraction and rigging of Gneisses. The agribusiness GIs cover several farming families, generating a value that goes beyond the economic, while the GIs of the extractivism are restricted in their productive chain due to the less need of manpower.

Evidence suggests that GI protects a pre-existing value without being the cause of local development. Regions with GI certifications such as those that belong Bento Gonçalves, Flores da Cunha, Monte Belo do Sul and Farroupilha were already traditional in the production and trade of wines. The GI registration only brought protection against possible unfair competition and market oscillations, ensuring the added value of the product.

The GNP per capita is an important statistic source for the economic knowledge of a given region, but only this data is not sufficient for a full understanding of its development. However, the surveyed regions that had the highest GNP per capita in relation to their state, are well developed and with high productivity, including products protected by GI. The regions that had GNP per capita expressively lower than that of their state, Salinas and Abaíra, are famous for the production of cachaça, and their respective states also have a lower per capita 
GNP than the other states surveyed. The lowest economic indicator does not determine that GI registration is poorly implemented in these places, as well as the high per capita GNP of the regions in relation to their states, can not determine the success of the GIs. What the study demonstrates is that regions where there is a notorious regional development and greater knowledge of how to manage business, are more likely to achieve GI registration and primarily succeed in their implementation.

The fact that the South and Southeast regions, which are the most developed in the country, having the highest number of GI registries reinforces the idea of the relationship between regional development, capacity of producers' organization and management in the success of GIs and may be the key to explaining their success. Instead of generating, the GI is by nature a consequence of the development installed in the demarcated areas. These aspects associated with the cultural factor favor the construction of a collective system around the GI, guaranteeing the involvement of all stakeholders.

Care must be taken when "adding value" is added to the "GI record", since this value, by legal definition, must already exist in the products, be they are famous for their production or with some unique quality. The contribution of the GI registry is its protection, ensuring that its producers will not be harmed by a fake or unfair competition.

The GIs of agribusiness come to bring this protection to a differentiated product, either by type of production or some specificity. This is very important for family farmers, as they usually work with subsistence farming. Not being able to compete with the large latifundia, they find themselves in need of investing in the quality of their products. Having quality is important to be it certified. Thus, the GI registry becomes a protection mechanism with a social appeal.

\section{Acknowledgements}

This work would not have been possible without the support of the Postgraduate Program in Intellectual Property of the Federal University of Sergipe and the Foundation for Research and Technological Innovation Support of the State of Sergipe (Fapitec/SE). Special thanks to the LADEC team.

\section{References}

Amaral Filho, J. (2001). A endogeneização no desenvolvimento econômico regional e local. Planejamento e Políticas Públicas, 13(23), 262-268.

Brasil. (1996). Regula direitos e obrigações relativos à propriedade industrial (Lei no 9.279).

Caçador, S. B., \& Monte, E. Z. (2015). Impactos dos royalties do petróleo nos indicadores de desenvolvimento dos municípios do Espírito Santo. Interações (Campo Grande), 14(2).

Cassano, F. A., Camelo, D. H., Padilha, F. P., Pereira, M. M., do Prado, M. D., \& Machado, V. F. (2017). Política Externa Brasileira nos Governos FHC, Lula e Dilma: Efeitos na balança comercial e no produto interno bruto brasileiro/Brazilian Foreign Policy Government FHC, Lula and Rousseff. Brazilian Journal of International Relations, 6(1), 61-89.

Coronel, D. A., Alves, F. D., \& Amaral, M. (2007). Notas sobre o processo de desenvolvimento da metade sul e norte do estado do Rio Grande do sul: uma abordagem comparativa. Perspectiva Econômica, 3(2), 27-43.

Fonseca Veiga, W. (2001). Contabilidade gerencial estratégica: O uso da contabilidade gerencial como suporte ao processo de gestão estratégica. Revista de Ciências Jurídicas, 2(2).

IBGE (Instituto Brasileiro de Geografia e Estatística). (2015a). Produto Interno Bruto dos Municípios. Retrieved from https://www.ibge.gov.br/estatisticas-novoportal/economicas/contas-nacionais/9088-produto-interno-br uto-dos-municipios.html? $=\& \mathrm{t}=$ conceitos-e-metodos

IBGE (Instituto Brasileiro de Geografia e Estatística). (2015b). Presidente Kennedy. Retrieved from https://cidades.ibge.gov.br/brasil/es/presidente-kennedy/panorama

IBGE (Instituto Brasileiro de Geografia e Estatística). (2015c). São Paulo. Retrieved from https://cidades.ibge. gov.br/brasil/sp/sao-paulo/panorama

INPI (Instituto Nacional de Propriedade Industrial). (2018). Pedidos de Indicação Geográfica Concedidos e em Andamento. Retrieved from http://www.inpi.gov.br/menu-servicos/indicacao-geografica/pedidos-de-indicac ao-geografica-no-brasil

Kauark, F. D. S., Manhães, F. C., \& Medeiros, C. H. (2010). Metodologia da pesquisa: Um guia prático. Itabuna/Bahia: Via Litterarum. 
Mankiw, N. G. (2014). Macroeconomía (5th ed.). Rio de Janeiro: LTC.

Marconi, M. D. A., \& Lakatos, E. M. (2017). Fundamentos de metodologia cientifica (8th ed.). São Paulo: Atlas.

Mattei, L. (2014). O papel e a importância da agricultura familiar no desenvolvimento rural brasileiro contemporâneo. Revista Econômica do Nordeste, 45(5), 83-92.

Oliveira, F. G. D. L., \& Andrade, C. F. S. (2017). Ocorrência de Diatraea saccharalis (Lepidoptera; Pyralidae) em plantações de cana-de-açúcar (Magnoliophyta; Poaceae) em diferentes localidades, no município de Paraty (RJ). Ciência et Praxis, 2(04), 7-10.

Oliveira, F. M., \& Costa, S. M. A. L. (2014). Agricultura familiar no APL/Cachaça da região de Salinas: caso de sucesso da cachaça Terra de Ouro (pp. 1-25). VI Simpósio Reforma Agrária e Questão Rurais NUPEDOR.

Oliveira, R., \& Fraga, J. S. (2011). Integrando processos sociais e ecológicos: O metabolismo social de três sistemas produtivos históricos do Estado do Rio de Janeiro. Anais do XXVI Simpósio Nacional de História-ANPUH. São Paulo.

Paz, I. N., \& Baldisserotto, I. (1997). A estação do vinho: A história da estação experimental de viticultura e enologia: 1921-1990. Cadernos de Pesquisa, 5(3), 55-78.

Porter, M. E. (2009). Competição. Rio de Janeiro: Elsevier.

Silva, L. N., Silva, J. W., Lima, F. V. R., dos Santos, J. A. B., \& Bortoli, R. D. (2018). O uso da Indicação Geográfica no território brasileiro (pp. 1-10). IV Encontro Nacional de Propriedade Intelectual-ENPI.

Tonietto, J., Falcade, I., \& Taffarel, J. (2005). Indicação de procedência Farroupilha: Vinhos finos moscatéis. Embrapa Uva e Vinho-Fôlder/Folheto/Cartilha (INFOTECA-E).

Tonini, H. (2008). Políticas públicas e turismo: Enoturismo no Vale dos Vinhedos/RS. PASOS: Revista de Turismo y Patrimonio Cultural. https://doi.org/10.25145/j.pasos

Vergara, S. C. (1990). Métodos de Pesquisa em Administração. São Paulo: Atlas.

Wharton, J. (2017). Subsistence agriculture and economic development. Abingdon: Routledge. https://doi.org/ $10.4324 / 9781315130408$

\section{Copyrights}

Copyright for this article is retained by the author(s), with first publication rights granted to the journal.

This is an open-access article distributed under the terms and conditions of the Creative Commons Attribution license (http://creativecommons.org/licenses/by/4.0/). 